
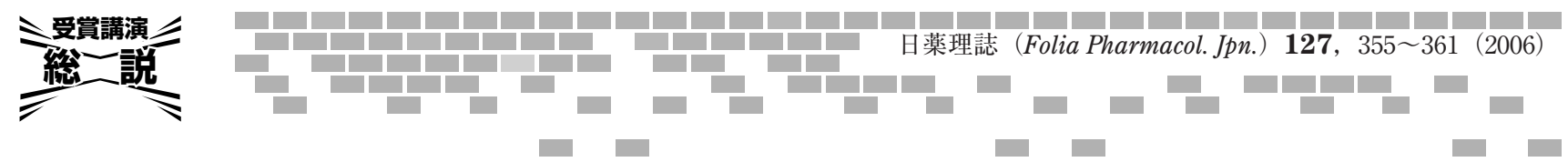

\title{
苔状線維発芽は側頭てんかんの 治療ターゲットとなるか
}

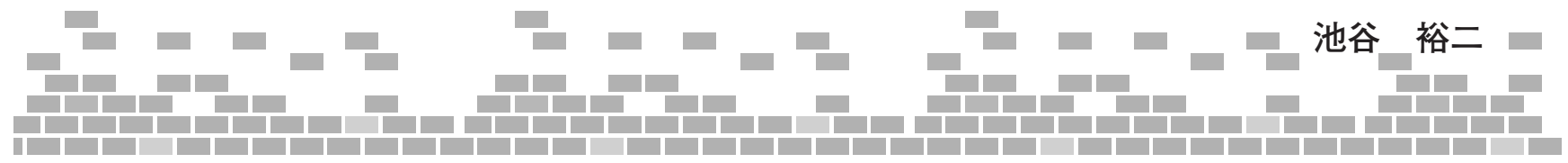

要約：海馬苔状線維は歯状回顆粒細胞の軸索である. この軸索は歯状回門で束状化し, 透明層と呼ばれる带 状の領域内を投射しながら，歯状回門や海馬 CA3 野 の標的細胞とシナプスを形成する.しかし側頭葉てん かん患者の海馬では，この投射パターンがしばしば崩 壞している. 苔状線維は歯状回門で異常分岐し, 歯状 回の内側分子層でシナプスを形成する。これは「苔状 線維発芽」とよばれ，ヒトだけでなく側頭葉てんかん のモデル動物でも確認されている. 同現象が注目を集 める理由は, 発芽によって顆粒細胞が再帰型の興奮入 力を受けるようになるためであり,この異常回路から 過剩な神経活動が発せられるものと想定される. 本総 説では苔状線維が異常発芽するメカニズムとその結果 に焦点を当て，てんかん原性にどのように関与するの かを考える．近年の発見を考慮すれば，発芽は軸索誘 導の分子機構の破綻であると捉えることができる。こ れを踏まえ, 異常発芽の予防が側頭葉てんかんの治療 につながる可能性についても考察したい.

\section{1.はじめに}

側頭葉てんかんは成人にみられるもっとも一般的な 難治性てんかんであり，側頭葉に端を発する自発的な 進行性てんかん発作によって特徵づけられる(1). 海 馬にいくつかの病理的所見が認められるが, 苔状線維 発芽はその中でもとりわけ頻繁に生じる現象であり (2-12), 実験動物モデルでも再現性よく観察される (13-20). 苔状線維は通常, 歯状回門と透明層内を投 射し, 歯状回門細胞や CA3 野の神経細胞とシナプス を形成するが $(21)$, 側頭葉てんかん患者では, 苔状線 維の側枝が歯状回の内側分子層で異常シナプスを形成 し (22), 顆粒細胞の樹状突起と再帰型の興奮性回路を
形成する (23)。この異常な回路再編成により，海馬は 過興奮に陥ると考えられる。ただし, 苔状線維発芽が 側頭葉てんかんにどう関与するかは諸説相乱れている 状態である．苔状線維はてんかんと無関与であると主 張する研究者もおり, これは主に, 苔状線維発芽の程 度と発作数や発作持続時間がほとんど一致しないとい う実験結果に基づいている(24-28)。この総説では， 近年の多数の文献を総合的に考えることで, 苔状線維 の側頭葉てんかんへの関与を再考するとともに, 苔状 線維発芽が治療のターゲットになりうるかという現実 的な問題についても考えてみたい.

\section{2. 側頭葉てんかんと苔状線維発芽}

苔状線維のシナプス形成の異常は側頭葉てんかんの 海馬組織においてほぼ普遍的に観察される $(4,5,8,13$, 16）が，その程度は側頭葉てんかんのステージによっ て異なる (10). 苔状線維発芽を検出するためのもっと もシンプルな実験手法は Timm 染色法である.これは, 苔状線維シナプスが亜鉛イオンを多量に含んでいるこ とを利用し, 銀還元反応によって苔状線維のシナプス 終末を選択的に検出する組織化学染色法である $(21,29$, 30). この染色によって, 固定脳標本や新鮮凍結切片, 組織培養された海馬標本などにおいて, 苔状線維のマ クロ分布を解析することができる．さらに詳細な形態 解析が必要な場合にはビオシチンを用いた細胞内染色 法やその他の神経トレーサーを用いることもある (14, 20)。これらは単一細胞レベルでの解析が可能であり, この手法によって, 側頭葉てんかん患者の海馬体では, 苔状線維が歯状回門領域で異常分岐し，一方はCA3 野方向へ，もう一方は分子層に伸長して抢り，顆粒細 胞同士が単シナプス結合しているといった詳細を捉え

キーワード：側頭葉てんかん, 海馬, 顆粒細胞, 軸索誘導, 苔状線維発芽

東京大学 大学院薬学系研究科 薬品作用学教室（†113-0033 東京都文京区本郷 7-3-1)

e-mail: Ikegaya@mol.f.u-tokyo.ac.jp 原稿受領日 : 2006 年 1 月 31 日, 第 21 回日本薬理学会学術奨励賞受賞講演総説 Title: Potential roles for mossy fiber sprouting in temporal lobe epilepsy

Author: Yuji Ikegaya 
ることが可能になった。（図 1)

実験動物によるてんかんモデルにはいくつかの種類 がある. 代表的なものとしてはラットを用いたカイニ ン酸モデル，ピロカルピンモデル，キンドリングモデ ルなどである。これらはヒトの側頭葉てんかんの特定 の側面をよく模倣しており, 苔状線維発芽の形態学的・ 生理学的な解析に広く利用されている(31)。こうした 研究の大多数は, 苔状線維が発芽によって顆粒細胞に ポジティブ・フィードバック型の回路を形成するとい う，いわゆる「再帰性興奮」仮説を支持している，す なわち, 再帰型回路が顆粒細胞の相互興奮を誘導し, 発作性活動の焦点となるという考え方である. 実際, 発芽した苔状線維は顆粒細胞の樹状突起とシナプスを 形成していることは電子顕微鏡によっても明らかにさ れている $(20,23,32)$. 電気生理学的な研究からも, 苔 状線維発芽した歯状回がてんかん様活動を示すことが 証明されている。このように，てんかん患者やてんか んモデル動物をもちいた研究から苔状線維発芽に関し て膨大な知見がもたらされてはいるものの, その研究 はまだまだ進行中であるといってよいだろう。以下に 各ポイントを整理したい。

\section{3. 再帰性興奮の形態学的証拠}

再帰性興奮仮説は現在ひろく受け入れられてはいる が, 逆の仮説, すなわち「再帰性抑制」仮説もまた存 在する。すなわち発芽した苔状線維の一部は歯状回の 抑制性インターニューロンとシナプスを形成し(19, 33），それによって顆粒細胞の興奮性を抑制している という考え方である.この仮説は, 苔状線維発芽は過 剩興奮性を導くものではなく, すでに過剩興奮してい る海馬の異常活動に拮抗し, てんかん様発火の伝播を 抑制するための防御機構であるという主張である。た だし，正常な海馬でも苔状線維シナプスの $90 \%$ 以上 は GABA 性神経細胞にシナプス結合を形成している 点は重要である (34). 正常な状態では苔状線維は顆粒 細胞とはシナプスを形成していないことを考慮すれば, 抑制性シナプス数がわずかに増加することよりも，興 奮性の再帰型回路が無から生まれることのほうが生理 的なインパクトは大きいと考えられる.

苔状線維はグルタミン酸を神経伝達物質としている が，GABAもまた利用しているという報告がある(35). 興味深いことに, 発作活動によって苔状線維終末の GABA およびその合成酵素である GAD67 の発現が上 昇する(36-39)。こうした現象もまた再州性抑制仮説 の支持基盤となっている. しかしその一方で，亜鉛イ オンによる $\mathrm{GABA}_{\mathrm{A}}$ 受容体の阻害作用がてんかん海馬
では劇的に増幅されてもいる。おそらくこれは GAB$\mathrm{A}_{\mathrm{A}}$ 受容体サブユニットの構成変化によるものだろう (40-42). 苔状線維から亜鉛イオンが大量に放出され ることを考慮すれば(30)，再帰型回路において GABA 性受容体が本当に生理機能を有してしているかどうか は今後の検討を待たねばならない.

一方, 最近の電子顕微鏡解析の結果, 発芽によって 新たに形成される苔状線維シナプスの大多数は非対称 シナプスであり (32), 顆粒細胞の樹状突起スパインを シナプス結合していることが示されている(23)。これ は興奮性シナプスの特徵である.また Buckmaster らは, ピロカルピンモデルにおいて 1 本の苔状線維あたり平 均約 500 個のシナプス数の増加があり，そのうち GABA 性神経とシナプスを形成しているのは 25 個以 下であることを示している(23)。したがって，数字の 上からいえば発芽の影響は興奮性シナプスに対しての ほうが圧倒的に強いといえる。なお，発芽した苔状線 維は顆粒細胞層内ではほぼ $7 \mu \mathrm{m}$ 間隔で，また分子層 内に拈いてはほぼ $3 \mu \mathrm{m}$ 間隔でシナプスを形成してい るが, 線維が起始する顆粒細胞の樹状突起の領域とは 重なっていない(23)。つまり, 発芽した苔状線維は親 細胞とは別の顆粒細胞にシナプス形成することで再帰 型回路を形成してことになり, 自己シナプス（オータ プス）を避けるような強力なガイダンス機構が存在し ているものと想像される.

\section{4. 再帰性興奮の生理学的証拠}

種々のタイプのけいれんが断続的に絶え間なく続く 重度の発作を「てんかん発作重積状態」とょぶ.てん かん発作重積状態を示した実験動物の海馬を電気生理 学的に追跡することで, 再州型興奮回路の機能につい ての直接的な証拠が得られている。たとえばカイニン 酸処置ラットの海馬スライス標本において, グルタミ ン酸を分子層や顆粒細胞層に局所適用することで, 適 用箇所からかなり離れた位置でも興奮性シナプス後電 流 (EPSC)（43）や興奮性シナプス後電位 (EPSP) (44) が惹起されることが報告されている。 $\mathrm{GABA}_{\mathrm{A}}$ 受容体 拮抗薬であるビククリンによって抑制性伝達を阻害す ると, 顆粒細胞層へのグルタミン酸投与は連続した EPSP とそれにともなうバースト発射が誘導される. キンドリングラットでも発作の 1 週間後に同様な現象 が報告されているが，苔状線維発芽のまだ生じていな い2 4 時間後では異常発射は生じない(44).

電気刺激の実験からも, 苔状線維発芽に起因した歯 状回の過剩興奮が示唆されている. ビククリンを添加 したり, 高カリウムイオン濃度にしたりと興奮性を高 

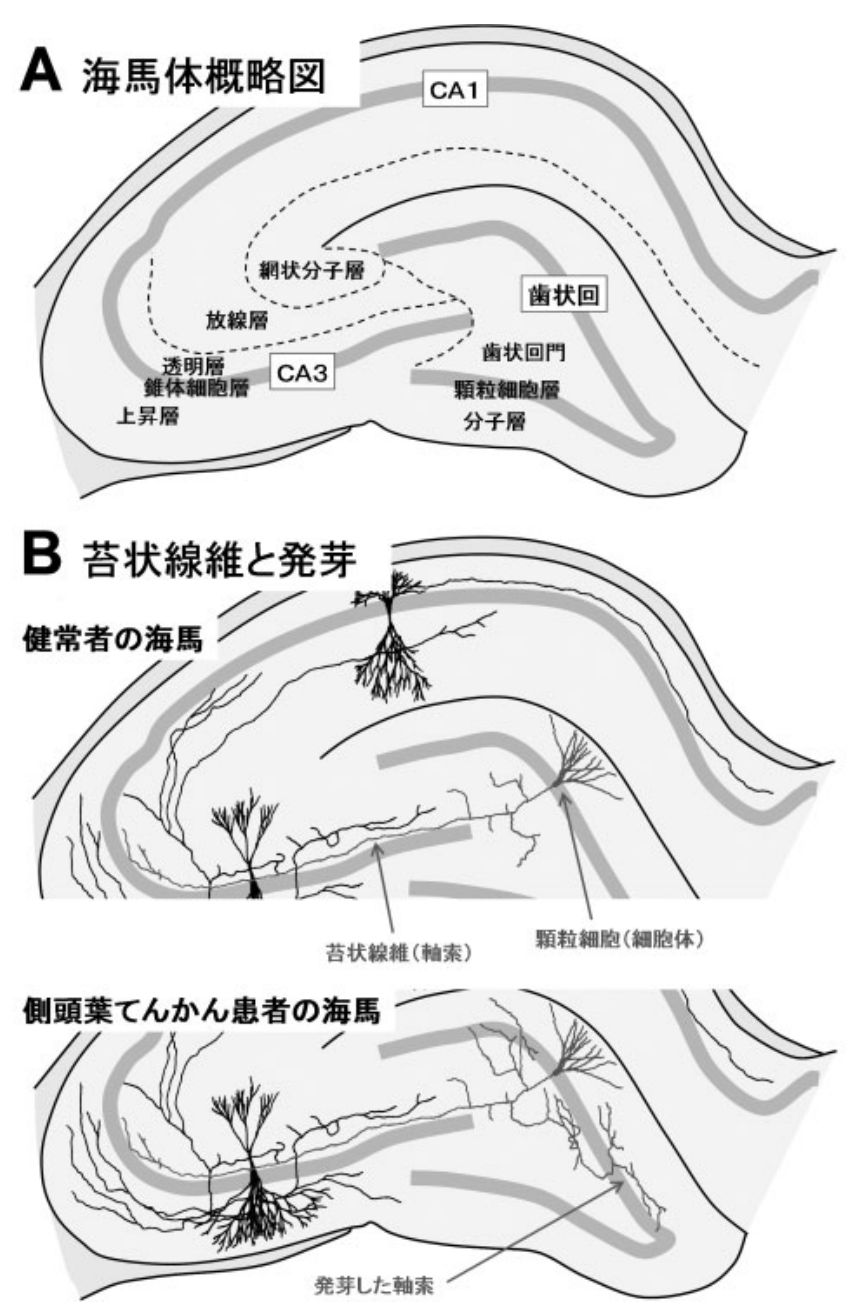

図 1 海馬体と苔状線維の概略図

$\mathrm{A}$ : 海馬体の微細構造亡各部位の名称, B : 顆粒細胞と苔状線維 の投射パターンの模式図. 上：正常な苔状線維, 下：側頭葉てん かん患者でしばしば観察される発芽した苔状線維

めるような工夫をして，カイニン酸てんかんラットの 顆粒細胞を逆行性に刺激すると，持続的なてんかん様 発火が顆粒細胞層に生じ，これに長い陰性場電位が続 くのが観察される (45). ホールセル記録で逆行刺激に よって生じる EPSC をモニターすることで，顆粒細胞 が非同期活動しているときには再帰型形路は機能的に はサイレントであるが，高頻度の入力では同期スパイ クを発するようになることが示されている(46)。こう した短期可塑性が，動物の行動状態に依存する断続的 な発作の基礎規定になっている可能性がある。

貫通線維の刺激実験によっても苔状線維の再帰型回 路の特性が伺える．貫通線維とは嗅内野皮質から顆粒 細胞の樹状突起に投射する外部入力線維である。側頭 葉てんかん患者の生検海馬から作製したスライス標本 では，貫通線維を刺激すると顆粒細胞に持続的な陰性 場電位が誘導される $(9,47)$. カイニン酸モデルラット
においても，通常ならば 1 回のスパイクしか生じない 貫通線維の単発刺激によって, $3 \sim 12$ 発の多重スパ イク発射が惹起される(48).ささらに，この後 $0.14 〜$ 1.5 秒程度の持続性陰性場電位が生じ, そこにいくつ かの不規則な遅延性集合スパイクが重なりながら，い わゆるてんかん様神経活動が形成される。こうした異 常発火は内側分子層にTimm シグナルが観察された 海馬スライスでのみ観察される。これらのデー夕は嗅 内野皮質からのシナプス入力が（たとえ入力シグナル が正常なものであっても）苔状線維の再帰型回路を通 じて，てんかん様活動へと過剩増幅されることを示し て抢り，海馬がてんかん原性に関与するという「再帰 性興奮」仮説を支持している.

てんかんモデル動物をもちいた in vivo 実験に，苔 状線維発芽の進行と発作の進行に正の相関があること を示すものある. Sutula ら (14) は，キンドリングラ ットの苔状線維終末の空間分布を調べ, Timm 陽性シ ナプスは発作が進行するにつれて徐々に分子層に現れ てくることを示している. Cavazosらは, Timm染色 強度と, 貫通線維によって惹起されるスパイク後発射 の程度やクラス $\mathrm{V}$ 発作をスコア化することで, 苔状 線維発芽と後発射とには $r=0.91$ の, またキンドリ ング発作とには $r=0.91$ の有意な正相関があること を証明した (49)。こうした電気刺激に対する感受性の 変化は最終発作の後 8力月以上も持続し, 回路変性は 長期的に持続することが伺える.

ホールセル・パッチクランプ記録をもちいて苔状線 維発芽と顆粒細胞の興奮性の関連を追求した研究もあ る. 岡崎らはピロカルピン処置したラットの苔状線維 を逆行刺激すると顆粒細胞にグルタミン酸作動性の EPSC が惹起されることを報告している (50)。この EPSC はてんかん発作重積状態に達した 10 週間後の ラットで $74 \% の$ 顆粒細胞で記録されたが, 苔状線維 発芽がまだほとんど生じていない 4 ～6 日後ではわず か $5 \%$ に観察されるのみであった. Scharfman らは 2 細胞から同時記録を行い，相互にシナプス結合した顆 粒細胞ペアの存在を証明している(51). Wuarin と Dudek はケイジドグルタミン酸を用いて顆粒細胞層 を刺激することで, 苔状線維発芽の進行と顆粒細胞に 生じる EPSC の関係を追跡している (52).カイニン酸 投与の 1-2, 2-4, 10-51 週間後の時点でそれぞれ検討 したところ，EPSC の大きさと頻度は Timm スコアの 進行とともに増大することが判明した。こうした知見 だけを眺めると, 苔状線維発芽はてんかん発作の原因 となっているという仮説に矛盾しないかのように思わ れる. 次の節ではこの可能性について議論してみたい。 


\section{5. 苔状線維発芽は側頭葉てんかんの原因なの か結果なのか}

苔状線維の発芽が歯状回ネットワークの再編成を誘 導し, その結果, 回路の過興奮を引き起こすという点 については多くの証拠が得られているが，その一方で， 再帰型回路が実際に発作の源になっているかという点 については確証的データが少ない。たとえば，Timm 強度と発作頻度にはほとんど関係がないというデー夕 がいくつかの研究グループから報告されている $(18,28$, 53).さらに苔状線維発芽が生じている海馬スライスで, GABA 受容体拮抗薬や高カリウム刺激で興奮性を高め ても，てんかん様発火を生じなかったという報告もあ る $(44,45,54)$ 。こうしたデー夕は苔状線維発芽がてん かん原性に重要であるとする仮説に疑問を投げかけて いる. 同様な批判はタンパク合成阻害薬であるシクロ ヘキシミドを用いた研究からも指摘されている $(24-26$, 55). 苔状線維発芽は少なくとも部分的には歯状回門 に存在する苔状細胞の脱落が原因で生じると考えられ ている (6, 45, 56-58). シクロヘキシミドは苔状細胞 (と 考えられる calcitonin gene-related peptide 陽性細胞) の脱落を抑制し，苔状線維の発芽の発生を抑える (59)。 すなわちシクロヘキシミドは苔状線維発芽の結果とし て何が生じるのかを調べるためのよい薬理学的なツー ルである. 面白いことに同薬はピロカルピンやカイニ ン酸モデルでのてんかん発作を抑制しないのである. つまり, 苔状線維発芽は発作の発生には必要でないと いうことになる。ただし, Williams らは, シクロへキ シミドはそもそも苔状細胞脱落も苔状線維発芽も抑制 しないことを報告しており，断定的な結論は待たねば ならない $(60)$.

こうした報告を考えると, 苔状線維発芽は側頭葉て んかんの原因なのか, それとも単に結果にすぎないの かという根本的な疑問が生じる. これを追求するため に, Nissinen らは, 外側扁桃体キンドリングモデルに おいて, 苔状線維発芽がてんかん発作のごく初期のス テージで生じるのか, または重度のてんかん重積発作 を発するようになってから生じるのかを検討した (28)。 結果として彼らは発作が現れ始めることと苔状線維発 芽には相関がないことを見いだした。また，発達期熱 性けいれんモデルにおいても, 苔状線維発芽はてんか ん原性には関与していないことが知られている $(61$, 62).こうした報告から, 苔状線維は少なくともてん かん初期においては，発作の原因というよりは，むし ろ結果であると結論づけられてよいだろう。

しかしながら, 苔状線維発芽が興奮性の再帰型回路
を形成することは明白な事実であり，苔状線維発芽が 側頭葉てんかんの慢性化の基礎過程になっている，も しくは側頭葉てんかんを悪化させる方向に寄与してい る可能性は十分にありうる. Zhang らの報告はこの説 を支持している。彼らはラットをカイニン酸で 2 回予 備処置したうえで, 3 度目の投与で発作を誘導した (63)。 こうしたプライミングを経ることでラットは苔状線維 発芽を呈しなくなる。このラットはてんかんの初期進 行過程においては, 通常のカイニン酸モデルと同程度 の発作を示したが，慢性相においては発作が有意に軽 微であった。すなわち, 苔状線維発芽は側頭葉てんか んの原性獲得には必須なプロセスではないものの, 発 作を増悪させる方向に関与していると考えられる.

\section{6. 軸索ガイダンス機構の破綻と苔状線維発芽}

次に苔状線維発芽の機構について考察する。通常, 苔状線維は歯状回門と明瞭層内を伸長する (21)。こう した層特異的な軸索伸長を達成するためには，高度な 軸索誘導システムが必須である。筆者は発達期に応じ て苔状線維の軸索ガイダンス機構がスイッチするとい う「2 ステップモデル」を提唱している (64).すなわち， 発達の初期においては, 苔状線維は主にCA3 野側か ら発せられる化学誘引因子と CA1 野からの反発因子 によって誘導されるが $(65)$, 発生後期では非拡散性の 接着誘導因子よって誘導されるというものである. 接 着対象は既に伸長を終えた苔状線維そのものであると 考えられた。これは, 歯状回スライスを化学固定した アンモン角のスライス標本と共培養するという巧妙な 組織培養法を利用して得られたものである(64)。固定 した標本では拡散性の誘引物質が放出されないが, そ れでもなお苔状線維は正しい標的を選択することが可 能であった。この軸索誘導は N グルコペチダーゼの 処置によって消失したことから，苔状線維に強く発現 する polysialylated neural cell adhesion molecule (PSANCAM）が非拡散性のガイド分子として機能してい ると想定された。

この 2 ステップモデルのアイデアを用いることで, 側頭葉てんかんにおける苔状線維発芽を説明できるか もしれない. 発芽にはすくなくとも2つの異なるプロ セスが必要である。一つ目は苔状線維の軸索が異常に 分岐する過程である。この分岐は歯状回門で生じる. 二つ目はこうして分岐した軸索が分子層に異常伸展す る過程である。

一つ目のプロセスはてんかん様発火によってトリガ ーされる、筆者は組織培養をもちいて, $\mathrm{GABA}_{\mathrm{A}}$ 受容 体拮抗薬が苔状線維の発芽を誘導することを示してい 
る(66)。この発芽は電位感受性ナトリウムチャネル阻 害薬テトロドトキシンによって阻害されることから， 過剩神経活動は発芽形成の十分条件である。神経活動 と発芽を関連づける候補分子は脳由来神経栄養因子 BDNFである.BDNFの転写抢よび翻訳はてんかん モデル動物の海馬で上昇している(67-73)。とりわけ 苔状線維の走行する領域にBDNF タンパク質の発現 が誘導されることから，歯状回門での活動依存的な BDNF の放出が苔状線維の分岐プロセスを誘導する のではないかと想定される。実際, BDNFを歯状回 門に局所適用するだけで苔状線維発芽が誘導される (74).この BDNF の効果はテトロドトキシンで神経 活動を阻害しても消失しなかったことも, 過剩神経活 動 $\rightarrow$ BDNF 放出 $\rightarrow$ 苔状線維発芽というストーリーを 強く支持している。

苔状線維発芽に必要な二つ目のプロセスは, 分岐し た軸索側枝が内側分子層に逆行性に異常伸長すること である.CA3 野に誘引分子が存在するにもかかわらず, なぜ分岐した苔状線維は CA3 野とは逆の方向に伸び るのだろうか. 通常, 軸索誘導システムは単一のガイ ダンス分子によって担われるのではなく, 数種の異な るメカニズムの均衡の上に成立している $(75,76)$ 。し たがって一つの可能性は, 正常であれば協調作業して いる誘導因子の複合システムが崩壊することであると 考えられる. セマフォリン・ファミリーの Sema3A は 候補分子の一つである. Sema3A は neuropilin-1/ plexinA 複合受容体のリガンドであり, 強力な軸索反 発因子として働く $(77,78)$. Holtmaat らは, 嗅内野皮 質の星状細胞の Sema3A mRNA レベルが，てんかん 状態で低下することが苔状線維発芽と関係があるので はないかと推測している(79)。歯状回に投射する星状 細胞は通常は標的領域である分子層に Sema3F の濃度 勾配を作っており，これによって苔状線維の進入を防 いでいると考えられる。この防壁システムが崩壊する のが苔状線維発芽の原因になっているとする考えであ る.

逆行性軸索誘導のメカニズムは他にも考えられる. たとえば, 非拡散性分子による苔状線維ガイダンス機 構がそれである。すでに述べたように，非拡散性分子 による誘導機構は成熟した海馬において優位なメカニ ズムとなる。したがって, 異常分岐した苔状線維の成 長もまた非拡散性分子によって導かれると考えられる。 非拡散性分子の最有力候補は苔状線維自身に発現する PSA-NCAM である。拡散性分子が濃度勾配を形成す るのとは異なり，非拡散性の分子には一般に「方向」 の情報を持っていない。したがって, 分岐した苔状線
維が，すでに成長を終えている苔状線維に接着して伸 展するとき, その方向選択は二者択一の偶然に支配さ れる。すなわち, 正しいCA3 野方向と異常な分子層 方向を選択する確率は五分五分である.

この考えは筆者自身の最近の発見によって強く支持 される．金らは未成熟な顆粒細胞を海馬スライス標本 の上に播種し培養するというスライスオーバーレイ培 養法を確立し, 回路形成のプロセスを単細胞レベルの 解像度を用いて解析した (80)。その結果, 歯状回門の 上に播かれた顆粒細胞の約半数は，軸索を分子層側へ と異常に伸展させることが明らかとなった．このこと から，側枝が形成されさえすれば，あとは確率支配の もとで自動的に軸索が分子層に到着するものと思われ る.すなわち, 苔状線維の発芽のもっとも重要なプロ セスは, 軸索の伸長というょりも, 分岐形成にあると 考えられる。ただし未成熟な海馬では拡散性分子によ る軸索誘導がまだ行われているため, 非拡散性分子が 存在しても, 苔状線維は正常にCA3 野に到達するこ とができるだろう。つまり, 異常分岐点から CA3 野 の方向を正しく選択することができる。これこそが乳 幼児や幼若動物が，たとえ㾏攣発作を発しても苔状線 維発芽がほとんど生じない理由であると考えられる. スライスオーバーレイ培養法の結果によれば，分子層 に播種された顆粒細胞の軸索は分子層内を伸長するの みで，そこから外部に漏出することはなかった。これ は分子層が苔状線維の成長に適した環境となっている ことを示している．非拡散性因子を考慮せずとも，そ もそも苔状線維には分子層での成長を好む性質が備わ っている可能性もある。

顆粒細胞は成体海馬においても増殖するという極め て風変わりな特徵を持っている $(81,82)$.これに伴い, その軸索である苔状線維のすくなくとも一部は数週間 ごとに入れ替わっていると考えられる(83)．石と Rutishauser は, PSA 糖鎖を特異的に分解するエンドニ ユーラミニダーゼで幼若動物を処置すると, 一過性に PSA-NCAM 量を減少させ, これによって苔状線維に 異所性に誘導できることを見いだしている (84)。この 異常は一度生じてしまうと成体になっても消失しなか ったすすなわち異常投射は非可逆である。この結果は 苔状線維が成体海馬でも入れ替わっていることを考え ると不思議である。同様な報告は Pimentaらによっ てもなされている(85). 幼若ラットの limbic systemassociated membrane protein の機能を阻害することで 苔状線維の異常投射を引き起こすことができるが，こ の異常もまた成体になっても維持される，側頭葉てん かんにみられる苔状線維発芽もまた非可逆な現象であ 
ると考えられる $(49,86)$.

異所投射した苔状線維は自発的には元に戻らないと いう性質もまた，苔状線維成長の 2 ステップモデルを 考えると容易に理解できる。すなわち，すでに異所伸 長した苔状線維が存在していたのならば，顆粒細胞の 増殖によって新規に追加される若い苔状線維もまたこ の異常な軌道に沿って伸長してしまうだろうと考えら れるからである。であるとすれば, 苔状線維の異常投 射が非可逆であるのはむしろ当然とも言えるし，側頭 葉てんかんが慢性化しやすく, 通常, 治療困難である ことも納得がいく．また側頭葉てんかん患者やピロカ ルピンモデル動物の海馬で PSA-NCAM の発現量が増 大していることも (87-89), 苔状線維の異常発芽を頑 強なものにしている可能性がある.

こうした仮説に基づけば，苔状線維の発芽を解除す るための戦略は明白である。それは, 非拡散性の軸索 誘導メカニズムを阻害し, 拡散性分子の機能を高める ことである。これがみごとに作動すれば，かりに苔状 線維の異常発芽が生じようとも, 苔状線維を正常な標 的に導くことができるであろう。もしかしたら側頭葉 てんかんの治療に結びつくかもしれない，現時点では 残念ながら，いくつかの候補分子は同定されていると はいえ，この 2 つステップの誘導機構を担う正確な分 子機構は明らかになっていない $(84,85,90-96)$.ごく 最近, CA3 野の組織片を移植することで, 苔状線維 発芽を消失させることができることが報告された $(97)$. これは特定の条件の元では苔状線維発芽が可逆である ことを示す初めての報告であり, 今後の研究の進展が 期待されるところである。

\section{7. まとめ}

側頭葉てんかん患者やそのモデル動物の精力的な研 究の結果, 苔状線維発芽に関する膨大な知見が集積し つつある。しかしながら，すでに述べた通り，苔状線 維発芽と側頭葉てんかんの関係については一致した見 解が得られていない. 苔状線維発芽はてんかんの原因 となりうる要因の一つにすぎないという点は念頭にお いておく必要はあろう。ここでは苔状線維のみに照準 を絞ってきたが, 実際には海馬体は側頭葉てんかんに おいて神経細胞脱落や神経新生, 突起の形態変性, グ リオーシスなど様々な病変を示す (98). 苔状線維だけ でなく, CA1 錐体細胞の軸索も異常発芽することが てんかんモデル動物で示されている $(99,100)$. したが って, 苔状線維発芽がてんかんの原因か否か, という 問いに対して決定論的な解決を求めるような従来の議 論は，いささか単純すぎるといえるだろう。むしろ側
頭葉を含む海馬体全体を包括的に掌握する必要がある ものと思われる。

にもかかわらず, 苔状線維発芽という現象そのもの が依然として学術的に魅力的であることに変わりはな い. 側頭葉てんかんを考慮せずとも, 苔状線維の発芽 メカニズムとそれがもたらす回路機能の変化を追跡す ることの成果は, より一般的な意味で, 中枢神経系の 回路再編成や神経可塑性, 機能適応, 軸索誘導などの 広範な生理現象の機構解明へと汎化されるであろうし, そして, これはまた, 側頭葉てんかんに対して別の角 度から再び新たな洞察をもたらすものと期待されるか らである。

（注）苔状線維の研究を展開するにあたり, 東京大学・大 学院薬学系研究科・薬品作用学教室を主催している松木則 夫教授と前教授である齋藤洋先生には大変お世話になりま した．この場を借りてお礼申し上げます．また本総説の基 本的なアイデアは, 当時博士課程の学生であった小山隆太 君との日々のディスカッションの中で育まれたものである こともここに明記します。

\section{文献}

1) Engel J Jr. Epilepsia. 1998;39:1014-1017.

2) de Lanerolle, et al. Brain Res. 1989;495:387-395.

3) Sutula T, et al. Ann Neurol. 1989;26:321-330.

4) Houser CR, et al. J Neurosci. 1990;10:267-282.

5) Houser CR. Brain Res. 1990;535:195-204.

6) Babb TL, et al. Neuroscience. 1991;42:351-363.

7) Isokawa M, et al. J Neurosci. 1993;13:1511-1522.

8) Franck J, et al. Epilepsia. 1995;36:543-558.

9) Masukawa LM, et al. Brain Res. 1989;493:168-174.

10) Mathern GW, et al. J Neurosurg. 1995;82:220-227.

11) Mathern GW, et al. J Neurosurg. 1995;82:228-233.

12) Zhang N, et al. J Comp Neurol. 1999;405:472-490.

13) Cronin J, et al. Brain Res. 1988;474:181-184.

14) Sutula T, et al. Science. 1988;239:1147-1150.

15) Mello LE, et al. Epilepsia. 1993;34:985-995.

16) Represa A, et al. Hippocampus. 1993;3:257-268.

17) Okazaki MM, et al. J Comp Neurol. 1995;352:515-534.

18) Buckmaster PS, et al. J Comp Neurol. 1997;385:385-404.

19) Kotti T, et al. Exp Neurol. 1997;146:323-330.

20) Wenzel HJ, et al. Hippocampus. 2000;10:244-260.

21) Henze DA, et al. Neuroscience. 2000;98:407-427.

22) Sutula T, et al. J Neurosci. 1995;15:8295-8301.

23) Buckmaster PS, et al. J Neurosci. 2002;22:6650-6658.

24) Longo BM, et al. Epilepsy Res. 1998;32:172-182.

25) Longo BM, et al. Neurosci Lett. 1997;226:163-166.

26) Longo BM, et al. Epilepsy Res. 1999;36:233-241.

27) Pitkanen A, et al. Epilepsia. 2000;41 Suppl 6:S24-S29.

28) Nissinen J, et al. Hippocampus. 2001;11:299-310.

29) Danscher G, et al. Histochemistry. 1978;55:27-40.

30) Ueno S, et al. J Cell Biol. 2002;158:215-220.

31) White HS. Neurology. 2002;59:S7-S14.

32) Cavazos JE, et al. J Comp Neurol. 2003;458:272-292.

33) Sloviter RS. Neurosci Lett. 1992;137:91-96.

34) Acsady L, et al. J Neurosci. 1998;18:3386-3403.

35) Walker MC, et al. Epilepsia. 2002;43 Suppl 5:196-202.

36) Gutierrez R, et al. Eur J Neurosci. 2001;13:1371-1379.

37) Gutierrez R. J Neurophysiol. 2002;87:2562-2570.

38) Gomez-Lira G, et al. Exp Neurol. 2002;177:276-283. 
39) Ramirez M, et al. Brain Res. 2001;917:139-146.

40) Buhl EH, et al. Science. 1996;271:369-373.

41) Shumate MD, et al. Epilepsy Res. 1998;32:114-128.

42) Coulter DA. Epilepsia. 2000;41 Suppl 6:S96-S99.

43) Molnar P, et al. J Neurophysiol. 1999;82:1883-1894.

44) Lynch M,et al. J Neurophysiol. 2000;83:693-704.

45) Wuarin JP, et al. J Neurosci. 1996;16:4438-4448.

46) Feng L, et al. J Neurosci. 2003:23:5381-5390.

47) Isokawa M, et al. Neuroscience. 1996;72:31-37.

48) Patrylo PR, et al. Epilepsy Res. 1999;36:31-42.

49) Cavazos JE, et al. J Neurosci. 1991;11:2795-2803.

50) Okazaki MM, et al. J Neurophysiol. 1999;81:1645-1660.

51) Scharfman HE, et al. J Neurophysiol. 2003;90:2536-2547.

52) Wuarin JP, et al. J Neurophysiol. 2001;85:1067-1077.

53) Timofeeva OA, et al. Epilepsy Res. 1999;33:99-115.

54) Patrylo PR, et al. J Neurophysiol. 1998;79:418-429.

55) Longo BM, et al. Epilepsia. 2002;43 Suppl 5:203-208.

56) Cavazos JE, et al. Brain Res. 1990;527:1-6.

57) Masukawa LM, et al. Adv Neurol. 1997:72:53-68.

58) Houser CR. Adv Neurol. 1999;79:743-761.

59) Longo B, et al. Exp Neurol. 2003;181:57-67.

60) Williams PA, et al. J Neurophysiol. 2002;88:2075-2087.

61) Bender RA, et al. Hippocampus. 2003;13:399-412.

62) Raol YS, et al. Ann Neurol. 2003:53:503-511.

63) Zhang $X$, et al. J Neurosci. 2002;22:6052-6061.

64) Koyama R, et al. Dev Biol. 2004;267:29-42.

65) Mizuhashi S, et al. J Neurosci. 2001;21:6181-6194.

66) Ikegaya Y. J Neurosci. 1999;19:802-812.

67) Isackson PJ, et al. Neuron. 1991;6:937-948.

68) Gall CM. Exp Neurol. 1993;124:150-166.

69) Nawa H, et al. Eur J Neurosci. 1995;7:1527-1535.
70) Elmer E, et al. Neuroscience. 1998;83:351-362.

71) Rudge JS, et al. Exp Neurol. 1998;149:398-410

72) Vezzani A, et al. Neuroscience. 1999;90:1445-1461.

73) Binder DK, et al. Trends Neurosci. 2001;24:47-53.

74) Koyama R, et al. J Neurosci. 2004;24:7215-72२4.

75) Tessier-Lavigne M. Curr Opin Genet Dev. 1994;4:596-601.

76) Tessier-Lavigne M, et al. Science. 1996;274:1123-1133.

77) Kolodkin AL, et al. Cell. 1997;90:753-762.

78) Takahashi T, et al. Cell. 1999;99:59-69.

79) Holtmaat AJ, et al. Exp Neurol. 2003;182:142-150.

80) Kim JA, et al. Cereb Cortex. 2004;14:1358-1364.

81) Altman J, et al. J Comp Neurol. 1965;124:319-335.

82) Kaplan MS, et al. Science. 1977;197:1092-1094.

83) Gould E, et al. Proc Natl Acad Sci USA. 2001:98:10910-10917.

84) Seki T, et al. J Neurosci. 1998;18:3757-3766.

85) Pimenta AF, et al. Neuron. 1995;15:287-297.

86) Cremer H, et al. Mol Cell Neurosci. 1997;8:323-335.

87) Mikkonen M, et al. Ann Neurol. 1998;44:923-934.

88) Proper EA, et al. Brain. 2000;123:19-30.

89) Shan W, et al. J Neurosci Res. 2002;69:292-304.

90) Muller D, et al. Neuroscience. 1994;61:441-445.

91) Chen H, et al. Neuron. 2000;25:43-56.

92) Grimpe B, et al. J Neurosci. 2002;22:3144-3160.

83) Ikegaya $Y$, et al. Neuroscience. 2000;98:647-659.

94) Koyama R, et al. J Physiol. 2002;539:157-162.

95) Mizoguchi A, et al. J Cell Biol. 2002;156:555-565.

96) Yamada RX, et al. J Biol Chem. 2005;280:38020-38028.

97) Hattiangady, et al. Neuroscience, in press

98) Pitkanen A, et al. Lancet Neurol. 2002;1:173-181.

99) Esclapez, et al. J Comp Neurol. 1999;408:449-460.

100)Smith BN, et al. J Neurophysiol. 2001;85:1-9. 